\title{
ARTIKULASI RELIGI SAJAK-SAJAK BASUDARA DI MALUKU
}

\section{Brotherhood Verses in Religious Articulation of Moluccas}

\author{
Abu Muslim \\ Balai Litbang Agama Makassar \\ Jl. AP. Pettarani No. 72 Makassar 90222 \\ Email: al_0365@rocketmail.com
}

Naskah diterima tanggal 25 April 2013. Naskah direvisi tanggal 10 Mei 2013. Naskah disetujui tanggal 20 Mei 2013

\begin{abstract}
Abstrak
Penelitian ini adalah penelitian kualitatif deskriptif yang mengidentifikasi petuah bijak dalam masyarakat. Fokus penelitian berorientasi pada penelusuran nilai-nilai keagamaan dalam artikulasinya, dengan persaudaraan (kerukunan) sebagai tema besarnya. Analisis isi digunakan untuk mengkaji muatan kandungan etik riligiusnya. Pengejewantahannya diperoleh dari masukan para informan yang kompeten dielaborasi dengan teori-teori etika keagamaan yang berkaitan. Di Maluku, perwujudannya dapat dilihat pada kapata, pantong, jugulu-jugulu serta kearifan lokal dalam ikatan pela dan gandong yang memuat nilai-nilai budaya dalam wujud sastra. Pengaplikasiannya sangat mendukung aktualisasi nilai kerukunan. Kesemuanya menunjukkan relasi sosial yang tidak hanya sekadar menggambarkan prinsip hidup dan penghormatan antara satu dengan yang lainnya, tetapi pengamalannya dapat menumbuhkembangkan kerangka kasih sayang dan kerukunan hidup antar warga Maluku yang sangat heterogen, baik dari kesukuan maupun keagamaan. Secara teknis, hal ini melahirkan sebuah falsafah keberagamaan Salam-Sarane sebagai pola hidup beragama yang khas sebagai agama orang-orang bersaudara di bumi Maluku yang satu. Penguatan pemahaman petuah bijak berbasis keagamaan dapat mewujudkan sosok manusia Maluku yang utuh dan integral sekaligus menjadi harmoni religi untuk meningkatkan diri dalam kesadaran kolektivitas sebagai hamba yang bersaudara.
\end{abstract}

Kata kunci: petuah bijak, persaudaraan, religi, Maluku

\section{Abstract}

The descriptively qualitative research identified the wise advices of society in Maluku. The focus of the research was to explore the religion values of their articulation, with brotherhood (harmony) as the big theme. The analysis was used to study the content of religious ethic. The manifestation was obtained from the inputs of competent informants elaborated with the theories of related religious ethics. In Maluku, the manifestation can be seen in kapata, pantong, jugulu-jugulu and local wisdom which were integrated with pela and gandong containing cultural values in the form of literature. Its application supported badly the actualization of harmony values. Those showed the social relationship which did not only illustrate the life principles and the respect among others, but its experience also was able to develop the framework of love and life harmony among the Maluku people who are very heterogeneous, both tribal and religious. Technically, it created the religious philosophy 'Salam-Sarane' as the specific way of life in religion which taught that they were in brothers in Maluku land. The reinforcement of understanding wise advices based religiosity can realize perfect and integral Maluku human figure as well as become religious harmony to boost themselves on collectivity awareness as the creature that are in brothers.

Keywords: wisdom advices, brotherhood, religion, Maluku

\section{PENDAHULUAN}

$\mathrm{K}$ earifan lokal yang kuat dapat mempercepat rekonsiliasi konflik antarumat beragama. Setidaknya hal itulah yang menjadi sintesis dalam disertasi Yunus Rahawarin yang mengangkat judul "Kerjasama Antar Umat Beragama dalam Menyelesaikan Konflik di Kota Ambon dan Kota Tual Maluku". Dipaparkan, pembangunan perdamaian melalui kerjasama antarumat beragama 
pasca konflik di Maluku ternyata didukung oleh kearifan lokal dan hukum adat sebagai alat perekat yang masih ditaati oleh masyarakat. Di Tual, pranata-pranata sosial lokal/aturan adat masih berfungsi dengan baik dan menjadi alat yang ampuh dalam meredam konflik. Sementara di Ambon, tradisi pela dan gandong, makan patita, masohi telah mengalami degradasi dan tidak dipatuhi lagi oleh masyarakatnya. Akibatnya, Ambon tidak memiliki kekuatan lokal yang dapat dijadikan sebagai alat peredam konflik. Dari realitas ini diharapkan masyarakat memberikan apresiasi terhadap nilainilai adat. Karena telah terbukti, betapa nilai kearifan lokal dapat mempercepat integrasi bilamana terjadi konflik antaragama. Oleh karena itu, menghidupkan kembali budaya-budaya lokal adalah hal yang sangat penting sebagai alat perekat sosial. Pelestarian dan pemahaman budaya dan kearifan lokal diharapkan dapat menguatkan karakter masyarakat Indonesia, di tengah masyarakat yang semakin modern, multikultur dan sangat cepat berubah. Masyarakat aman adalah masyarakat yang berbudaya.

Kebudayaan adalah hasil cipta manusia, dan nilai-nilai dalam kebudayaan itu (nilai budaya) menjadi kekuatan penggerak bagi manusia untuk beraktifitas. Sebagai hasil karya manusia, maka dengan sendirinya kebudayaan membuka ruang penilaian dan pengoreksian terhadap pelaksanaan nilai itu maupun penilaian dan pengoreksian terhadap kekuatan berlakunya nilai itu bagi kepentingan masyarakat. Di Maluku, posisi nilai budaya yang sangat lokal dan hanya mengikat secara terbatas menjadi statuta bebas yang rentan dibenturkan, lokalitas berbasis etnis dan agama menjadi sebuah bangunan pemicu pertentangan antarkomunitas (Waileruny, 2009:152). Akan tetapi, jika nilai itu dijadikan sebagai alat kontrol sosial melalui pendekatan kearifan lokal masyarakat dengan memunculkan kembali aksen positif dari petuah bijak yang telah menyejarah, maka kekhawatiran terhadap hal-hal yang dapat memicu intoleran dan perpecahan bisa dihindarkan.

Interpretasi seni dan budaya Maluku misalnya, ketika direfleksikan dalam nyanyian dan tarian telah dianggap sebagai bagian dari tradisi adat dan agama yang masih berlaku pada setiap wilayah di Maluku. Ketika musik dan tarian diafirmasikan dalam kultur kolonial pada abad sembilan belas, orang Maluku mulai mengenal lagu-lagu religius dalam bentuk hymne. Masyarakat Maluku mempraktikkan hymne-hymne lagu tersebut di Gereja-Gereja
Protestan yang tersebar di hampir setiap sudut kota Ambon. Hibriditas tampilan antara musik, tarian dan nyanyian adalah hasil kolaborasi budaya antara keragaman nyanyian-nyanyian lokal dengan instrumen kolonial (Abdul Kadir, 2008:40).

Dalam perkembangannya, tradisi itu menjadi potensi kuat dalam penciptaan syair-syair modern yang kandungan isinya banyak memuat aspekaspek dasar perekat kerukunan. Oleh karena itu, penggalian nilai-nilai keberagamaan anak negeri Maluku dalam konteks komunikasi budaya harus bisa menjawab tantangan zaman yang mengusung tema modernitas sebagai perangkat utama dalam menggerus nilai-nilai budaya lokal masyarakat.

Sementara itu, interaksi sosial berbasis budaya lokal (dimana aspek moralitas etik masyarakat menjadi sasarannya) di era modern saat ini justru menjadi sesuatu yang mewah untuk diperbincangkan (setelah lama tergerus oleh kemajuan dan globalisasi). Oleh karena itu, penanaman nilai-nilai budaya dan kearifan lokal menjadi mutlak untuk dibangun kembali, lebih khusus pada daerah-daerah yang rentan terjadi pergesekan-pergesekan identitas (seperti Maluku misalnya, yang kini berada dalam tahap membangun kembali toleransi dan perdamaian pasca konflik 1999). Ragam kearifan lokal pada masyarakat Maluku sesungguhnya merupakan manifestasi dari anjuran-anjuran untuk senantiasa mengedepankan persaudaraan, perdamaian, toleransi dan kasih sayang.

Dengan demikian, kajian terhadap petuah bijak dalam kearifan lokal masyarakat menjadi penting untuk dilakukan dengan mempertimbangkan kebertahanan budaya serta kemanfaatannya bagi masyarakat. Pendekatan keagamaan adalah alternatif fokus kajian yang ditawarkan melihat besarnya ruang-ruang konflik yang bisa timbul jika agama dibenturkan (Ratnawati, 2006:111).

Galian-galian deskriptif kualitatif dilakukan untuk menemukan petuah bijak dalam masyarakat, dengan mendeskripsikan berbagai pemaknaan masyarakat terhadap petuah bijak tersebut, berdasarkan pada teori resepsi yaitu teori yang mementingkan tanggapan masyarakat terhadap karya sastra, misalnya tanggapan umum yang mungkin berubah-ubah yang bersifat penafsiran dan penilaian terhadap karya sastra (petuah bijak) yang ada dalam rentang waktu tertentu. Meski demikian, penguatan analisis pasca pemaknaan yang dilakukan oleh masyarakat yang berkompeten 
di bidangnya (tokoh adat, tokoh agama, budayawan, ilmuan pemerhati nilai-nilai lokal, dan lain-lain.) tidak begitu saja dijadikan sebagai alat tunggal dalam analisis data. Elaborasi nilai-nilai keagamaan juga dilakukan atas segenap teori yang berkaitan dengan fokus penelitian.

Karena penelitian ini mengambil agama sebagai gejala sosial dan budaya sebagai obyek kajian etis dalam pengejewantahannya, maka penelitian ini difokuskan pada penelusuran nilainilai keagamaan (religious research) dalam aspek budaya. Penelusurannya dapat dilihat dalam segenap sajak-sajak (petuah bijak) masyarakat dengan berorientasi pada aspek persaudaraan (termasuk juga di dalamnya aspek toleransi dan kasih sayang). Perumusannya dibungkus dalam permasalahan pokok yakni mengungkap nilai religi (keagamaan) yang terkandung dalam petuah bijak masyarakat maluku. Penegasannya terletak pada aspek religiusitas dalam setiap artikulasi petuah bijak yang hidup dan berkembang di lingkungan masyarakat.

\section{PEMBAHASAN}

Secara kultural, orang Maluku mempunyai ikatan persaudaran kuat. Tetangga dan rekanrekan dimediasi melalui berbagai lagu dan tarian. Nyanyian dan musik inilah yang menjadi identitas masyarakat Maluku sebagai jawaban atas tantangan modernitas. Dinamika ini diusung oleh peradaban Kristen Protestan pada masa kolonial. Sekolahsekolah pada akhir masa kolonial mengenalkan musik sebagai bagian dari kurikulum. Siswa-siswi diwajibkan untuk belajar tiga keahlian utama yakni: membaca, menulis dan menyanyi (lihat Abdul Kadir, 2008: 42). Karakteristik persaudaraan dan kasih sayang bagi masyarakat Maluku sejatinya bersumber dari petuah luhur tentang eksistensi orang Maluku dalam Kapita Asal Muasal Patasiwa Patalima, di dalamnya dengan tegas menganjurkan persaudaraan, kekeluargaan dan kasih sayang.

\section{Kuru Siwa Rima E}

Tutu ya hei lete hei lete oo,

Hei lete Nunusaku o, Nunusaku o;

Nunusaku karu pela, karu pela o.

Nunusaku sama pela, sama pela o;

Sama pela Wae le telu, Wae le telu o,

Nunu e, nunu e, Nunusaku nunu e;

Nunusaku Nusa Ina, Nunu Siwa Rima oo,

Nunusaku Nusa Ina, Upu Ama lepa Nia;
Tala, Eti, Sapalewa, Kuru Siwa - Rima ee, Upu Ama Karu Pela, Karu Pela o,

Berikut terjemah bebasnya (Lestahulu: 2012):

\section{Tempat Asal Patasiwa Patalima}

Pandanglah ke sana, mereka datang, turun dari darat

Datang dari kawasan Nunusaku, Nunusaku. Nunusaku mewariskan kita pela, ikatan persaudaraan

Nunusaku membawa serta pula ikatan kekeluargaan

Membawa lembaga pela dari kawasan tiga aliran sungai

Nunusaku, Nunusaku, dari sanalah asalnya

Nunusaku, Nusa Ina, janji para leluhur

Dari kawasan tiga aliran sungai Tala, Eti, dan

Sapalewa berasal masyarakat Patasiwa dan

Patalima

Para leluhur mewariskan pela ikatan persaudaraan milik bersama,

harus terpelihara.

Keberadaan dasar-dasar kerukunan yang berasal dari warisan leluhur sebagaimana tersirat dalam petuah yang menyejarah seperti ini, sangat potensial terpatri kuat di setiap jiwa-jiwa masyarakat Maluku. Konstruksi yang dibangun adalah penguatan ikatan kekerabatan sebagai kesatuan tanah leluhur/nenek moyang (baca: Nunusaku). Sebagaimana lazimnya orang-orang sedarah, sepantasnyalah untuk tidak saling berselisih, sebab nilai yang ditanamkan adalah moralitas kebersesamaan dan senantiasa hidup rukun. Sesungguhnya, jika saja pemahaman mendalam dan pengejewantahan nilai-nilai yang terkandung dalam petuah bijak (kapata dan yang lainnya) terpatri dalam karakter dan pola hidup masyarakat, seharusnya tidak perlu ada konflik di Maluku.

\section{Gambaran Umum Sajak-Sajak Maluku Pela dan Gandong}

Tanah Maluku mempunyai kekhasan kultur yang tidak dijumpai di daerah lain di Indonesia. Kultur tersebut dikenal dengan sebutan pela gandong. Pela gandong ini kerap menjadi kebanggaan masyarakat Maluku sejak dulu hingga sekarang. Pela diartikan sebagai suatu relasi perjanjian persaudaraan antara satu negeri dengan negeri lain yang berada di pulau lain dan kadang juga menganut 
agama yang berbeda, sedangkan gandong sendiri bermakna adik. Perjanjian ini kemudian diangkat dalam sumpah yang tidak boleh dilanggar. Menurut Dr. Soekanto, pela ialah ikatan persaudaraan atau persahabatan yang telah melembaga yang sudah terbentuk sejak dahulu kala dan bertugas untuk melakukan hal-hal tertentu demi kepentingan pihakpihak yang mengadakan ikatan itu. Definisi lainnya dikemukakan J. Manuputty: Pela adalah suatu ikatan adat yang terjadi dari suatu peristiwa penting dan mengakibatkan adanya jalinan persekutuan hidup secara kekeluargaan timbal-balik antara dua atau beberapa negeri (Cosmus Uneputty, 2005: 69-70).

Adapun empat hal pokok yang mendasari pela yaitu: negeri-negeri yang berpela berkewajiban untuk saling membantu pada kejadian genting (perang, bencana alam, dan lain-lain) jika diminta, maka negeri yang satu wajib memberikan bantuan kepada negeri lain yang hendak melaksanakan proyek kepentingan umum, seperti pembangunan sekolah, masjid, atau gereja; jika seseorang sedang mengunjungi negeri yang berpela itu, maka orangorang di negeri itu wajib untuk memberi makanan kepadanya dan tamu yang sepela itu tidak perlu meminta izin untuk membawa pulang hasil bumi atau buah-buahan yang menjadi kesukaannya. Penduduk negeri-negeri yang berhubungan pela dianggap satu darah, sehingga dua orang yang sepela tersebut dilarang untuk menikah. Bagi orang-orang yang melanggar segala ketentuan tersebut, konon katanya akan mendapatkan hukuman dari nenek moyang yang mengikrarkan pela. Sebagai contoh, seseorang ataupun keturunannya dapat jatuh sakit atau bahkan meninggal dunia bila melanggar ketentuan itu. Jika ada yang melanggar pantangan untuk menikah, maka mereka akan ditangkap untuk kemudian disuruh berjalan mengelilingi negeri-negerinya dengan hanya berpakaian daundaun kelapa, sedangkan seluruh penghuni negeri akan mencaci makinya (Rosalina, 2007).

\section{Kapata}

Kapata merupakan nyanyian yang menggunakan bahasa daerah/bahasa adat atau dapat dikatakan sebagai nyanyian tradisi. Bahasa adat ini hanya diketahui oleh orang-orang tua tertentu saja. Dalam adat orang Maluku, para kapitan hanya mewariskan tata cara adat ini kepada anak lelakinya yang tertua. Hanya mereka inilah yang berhak memimpin upacara-upacara adat termasuk kapata-kapata. Kapata biasanya dinyanyikan atau diperdengarkan bilamana sedang dilaksanakan upacara adat. Masyarakat Maluku pada umumnya masih taat pada petuah-petuah yang diberikan oleh leluhur mereka melalui kapata-kapata tersebut (Taman Budaya Maluku, 2004:5-6).

Kapata adalah tradisi menutur tentang peristiwa-peristiwa masa lampau, dibawakan secara resiatif (setengah bernyanyi setengah berbicara) (Christian J. Tamaela, 1995: 14). Kapata berasal dari kata kapa, pata, tita. Kapa artinya puncak gunung yang berbentuk tajam seperti jari telunjuk ke langit, Pata yaitu diputuskan secara definitif dan tidak dapat dirubah, Tita yaitu sabda, tegas. Jadi Kapata yaitu ucapan tegas yang tidak dapat dirubah, yang naik sebagai gunung berpuncak, tombak tertuju kepada Sang Pencipta. Dapat diartikan sebagai ucapan-ucapan yang suci dan mempunyai kekuatan yang dirahasiakan (Taman Budaya, 2004: 15).

Definisi lainnya menyebutkan bahwa kapata adalah nyanyian dalam bahasa tanah (bahasa daerah) yang sedikit banyaknya bersifat legenda dan menceritakan tentang kejadian penting dalam sejarah daerah atau suatu tempat. Karena jangkauan waktunya jauh ke belakang, maka tradisi lisan itu kebanyakan sudah mengambil bentuk mitos. Namun demikian, jika mitos-mitos tersebut ditelusuri secara seksama dan dihubungkan dengan sumber-sumber sejarah tertulis, maka peristiwaperistiwa masa lampau dapat diungkap pula (Taman Budaya, 2004:15).

Tidak ada orang yang tahu kapan dan oleh siapa kapata-kapata ini diciptakan. Akan tetapi, secara turun temurun masyarakat meyakini bahwa kapata telah ada bersamaan dengan kedatangan orang Portugis ke Maluku. Isi kapata umumnya menceritakan suatu peristiwa yang pernah terjadi/ dialami oleh sekelompok masyarakat atau orang tertentu. Kapata pada akhirnya disebarkan pula oleh para kapitan dari Nunusaku yang turun ke pantai dan daerah lain dengan menggunakan bahasa setempat dengan pemaknaan yang sama.

\section{Pantong dan Jugulu-Jugulu}

Salah satu bentuk tradisi lisan yang cukup popular di kalangan masyarakat Maluku adalah tradisi pantong. Pantong sebagai salah satu bentuk puisi lama menjadi alat penyuara kehidupan masyarakat Maluku pada umumnya dalam berbagai bentuk dan ragam bahasa daerah di Maluku. Mariana Lewier dalam makalahnya yang berjudul 'Tradisi Pantong dalam Nyanyian Desa Letwurung 
Kepulauan Babar Maluku Tenggara Barat" (2012), menyebutkan bahwa tradisi pantong menjadi identitas yang selalu dinyatakan dalam acara-acara adat maupun acara-acara khusus lainnya. Berikut ini salah satu pantong beserta terjemahannya (Takaria, 2011: 28)

Mari bermaeng layang-layang

mari bermain layang-layang

Ika ujung deng banang mengikat ujungnya dengan benang

Katong sambayang, Tuhan sayang

kita sembahyang disayang Tuhan

Bapa pigi deng senang

bapak berangkat dengan senang

Dari Pure pigi ka Candi

dari Pura pergi ke Candi

Lewat masjid deng Gareja

melewati Masjid dan Gereja

Punya iman yang tahang uji

punya iman yang tahan uji

Kalu mati masu di sorga

kalau mati masuk surga

Jangang sibuk mancari makang

jangan hanya sibuk mencari makan

Ia lupa Tuhang punya pasang

sehingga lupa pesan Tuhan

Tiap waktu musti sombayang

setiap hari harus sembahyang

Pasti Tuhang selalu sayang

pasti selalu disayang Tuhan

Baku pukol dengang sasapu

saling pukul dengan sapu

Cuma di Mamala, Morela,

hanya di Mamala, Morela

Orang nonton tersipu-sipu

orang yang menonton jadi tersipu

Tanda syukur abis puasa

tanda syukur telah berpuasa

Selain itu, di Maluku juga terdapat tradisi permainan jugulu-jugulu (teka-teki tradisional), sifat permainan adalah hiburan sekaligus pertandingan mengasah otak. Materi jugulu-jugulu umumnya berkaitan dengan mata pencaharian sehari-hari, kegiatan di dalam rumah tangga bahkan berbagai hasil pengamatan dan interpretasi terhadap alam dan lingkungan (Sahusilawane, 2002: 30).

Peristilahan yang digunakan seringkali tidak mengacu pada jawaban sebenarnya terhadap pertanyaan yang diajukan, tapi justru letak keunikan dari jugulu-jugulu ini adalah kemampuan memainkan bahasa dengan memperhatikan segenap persamaan unsur yang ada di dalamnya untuk dijadikan sebagai suatu kesatuan pertanyaan dan jawaban yang berkesinambungan.

\section{Nuansa Kerukunan dalam Artikulasi(Religi) Sajak-Sajak di Maluku}

\section{Saki' di Kuku Rasa Di daging \\ Sagu Salempeng dipata dua \\ Ale rasa beta rasa \\ Katong samua basodara}

Terjemahannya adalah sebagai berikut: jika kuku terasa sakit, sakitnya tembus ke daging; sepotong sagu dibagi dua; yang kau rasakan kurasakan juga; kita semua bersaudara. Maluku sebagai satu kesatuan wilayah secara statistik mencerminkan keterpaduan dua klen agama besar (tanpa mengabaikan eksistensi agama lainnya) Islam dan Kristen yang jika dikuantifikasi berada pada zona yang hampir berimbang. Hal ini menunjukkan betapa penguatan agama menjadi patron persaudaraan yang harus diperhatikan lebih serius dan mendalam. Konflik berdimensi sara yang terjadi tahun 1999 adalah klausul nyata betapa persoalan keagamaan pada wilayah dominasi agama yang berimbang menjadi dinamika kemasyarakatan rentan terjadi benturan.

Pada dasarnya, jejak keberagamaan anak negeri Maluku menunjukkan interaksi kerukunan yang harmonis. Bagi nenek moyang orang Maluku, agama bukan hanya sekadar pewahyuan yang hampa tanpa wujud, akan tetapi ia terinternalisasi melalui tatanan kearifan budaya yang pada gilirannya akan membawa manusia pada proses perdamaian yang terus menerus. Dalam konteks sosio-religi, kemajemukan dalam berkeyakinan adalah sarana efektif dalam kebersamaan hidup. Dinamika itu pula yang pada akhirnya melahirkan pola keberagamaan Salam-Sarane sebagai spesies "hidup beragama" yang khas dari anak negeri Maluku. Namun perlu dipahami bahwa Salam-Sarane bukanlah agama, tetapi cara hidup orang beragama dalam konteks agama-agama orang basudara. Salam (Islam) tetap dengan ketaatan keimanannya, begitu pula dengan Sarane (Kristen).

Keduanya menemui eksistensinya yang kokoh dalam konteks ke-Malukuan-an, yang secara de facto 
memiliki perbedaan, tapi sekaligus berada dalam ikatan tradisi kekeluargaan yang kuat. Inti dari falsafah Salam-Sarane ini adalah "how to be the good Moslem and how to be the good Christian" (bagaimana sesungguhnya menjadi Islam dan Kristen yang baik). Falsafah keberagamaan ini sesungguhnya terbangun dari sebuah penghayatan yang utuh terhadap nilai-nilai kearifan kultural masyarakat Maluku yang menghendaki ekspresi kehidupan satu dalam satu atau satu dalam kebersamaan yang menyatu (Watloly, 2005: 168-185).

Membangun kembali kearifan lokal dengan pranata keagamaan sebagai dimensi penguat adalah penting untuk dilakukan. Jika merunut kembali beberapa aspek petuah bijak yang telah dipaparkan sebelumnya, maka penonjolan-penonjolan terhadap artikulasi religi yang termuat dalam budaya lokal itu perlu dikedepankan. Salah satu yang menonjol dalam pranata hidup masyarakat Maluku adalah pela gandong, jika ini dipegang teguh, manfaatnya benar-benar positif kaitannya dengan penguatan nilai sosial budaya Maluku. Ikatan pela sejak dulu sudah mendarah daging, menjadi alat penangkal dan penghalang setiap ketegangan-ketegangan sosial yang terjadi.

Manifestasi pela gandong dalam ikatan toleransi dan persaudaraan antar negeri yang berbeda agama, akan banyak dijumpai di tanah Maluku. Salah satu yang menonjol adalah ikatan pela-gandong antara Pulau Nusalaut (yang dihuni oleh 7 negeri Kristen) dengan Pulau Ambelau (yang dihuni oleh 7 negeri Islam), keduanya saling menjaga dan melindungi dalam ikatan kakak adik. Selain itu juga dapat dijumpai ikatan pela yang berbeda agama dalam satu wilayah dengan terus menjaga hubungan baik atas sumpah yang telah diikrarkan nenek moyangnya, sebut saja misalnya: Batu merah (Islam) dan Passo (Kristen), Waai (Kristen) dan Morela (Islam), Hattu (Kristen) dan Wakasihu (Islam), serta Tengah-tengah (Islam) dan Hatusua (Kristen).

Ikatan tersebut juga banyak dijumpai dalam acara-acara adat dengan syair-syair yang selalu dibunyikan untuk memperkuat memori itu ke dalam dada para generasi penerus. Nyanyian itu disebut dengan kapata-kapata tradisional. Diantara kapata yang hidup di masyarakat, terdapat salah satu jenis kapata yang nuansa religiusitasnya sangat terasa yakni Kapata Mako-Mako. Kapata ini dipergunakan untuk memanjatkan doa seperti pengucapan syukur, menyampaikan hajat, menggalang tekad atau selamatan tentang hasil yang jelas dicapai dalam usaha. Isi lirik, umumnya berupa pujian yang mengagungkan Tuhan, kebesaran negeri atau kebesaran kepala negeri atau pahlawan yang dianggap berjasa kepada masyarakat. Kapata MakoMako, syairnya dua seuntai seperti contoh berikut:

\section{"Yana Siwa riosako mano mese,}

Yana Siwo rio saka mano mese,

Puti malalawa hai ria siri - ooooh,

Puti malalawa hai ria siri - ooooh,

Sin sin tatasin wame momo,

Sin sin tatasin wame momo,

Momo jane hua hua kira - kira oooh

Momo jane hua hua kira - kira oooh

One mana one roti sampa kalo

One mane one roti sampa kalo

Babu lua, batu lua roti sampa kalo

Babu lua babu lua roti sampa kalo

\section{Maknanya:}

Hai orang Siwa Lima jaga negerimu, Waspada di fajar menyingsing, Jangan sampai diserang musuh.

Hai orang muda rapatkan barisan, dengan penuh semangat siaga, Orang tua berdoa, mengatur siasat, sambil makan sirih dan pinang, supaya tidak mengantuk.

Secara leksikal, kapata tersebut menguraikan tentang sebentuk kerjasama yang terstruktur antar setiap jenjang generasi di Maluku. Kesungguhan untuk menjaga tanah air diartikulasikan dalam semangat persatuan dan kesigapan untuk saling menjaga antara satu dengan yang lainnya. Ikhtiar yang dilakukan adalah demi keutuhan dan keterjalinan rasa aman. Doa dipanjatkan atas manifestasi penghambaan kekhalik-makhlukan setelah segenap usaha dilakukan, hasil akhir adalah diserahkan pada keagungan Tuhan. Inilah yang bagi masyarakat Maluku mengurainya dalam hubungan vertikalhorizon, di sini segenap perbedaan terkubur dalam kerangka persatuan dan persaudaraan. Nur Tawainela, seorang tokoh adat Tulehu di Pulau Ambon menyebut hal ini sebagai sebentuk kekayaan kultur masyarakat Maluku yang diperoleh turuntemurun dan hanya bisa terpatrih dalam keluhuran tindakan serta harmonisasi seluruh masyarakat Maluku, bersamaan dengan penghayatan mendalam terhadap ikatan leluhur yang harus terus dipelihara secara kontinu (wawancara Nur Tawainela, 28/10/2012). 
Musik rakyat Maluku sampai sekarang masih sangat dipengaruhi oleh kapata-kapata ini, yang merupakan proses akulturasi dari warisan para leluhur. Lagu-lagu modern sejatinya adalah transformasi dari kearifan lokal kapata, penguatan identitas ke-maluku-an menjadi titik perhatian yang kebertahanannya tetap dilanjutkan. Sebut saja misalnya lagu Sio Mama yang sangat populer tidak saja di Maluku, bahkan di Indonesia. Lagu ini mencerminkan, betapa nilai-nilai luhur masyarakat Maluku yang menjunjung tinggi penghargaan terhadap kampung halaman, tercermin pula dalam ungkapan kerinduan kepada ibu sebagai pranata sosial yang memiliki tingkat penghargaan tinggi di mata orang-orang Maluku. Bagi orang Maluku rantau, mengingat ibu, sama rasanya dengan mengenang kampung halaman. Dalam catatan sejarah Maluku yang diperoleh dari kapata, bahwa Nunusaku atau asal tempat kejadian daerah Maluku di Pulau seram sering diikuti dengan frasa ibu sebagai tanah asal kelahiran dengan sebutan populer Nunusaku di Nusa Ina. Ina dalam bahasa Maluku berarti ibu, dalam arti yang diperluas, Nunusaku adalah ibu pertiwi bagi orang-orang Maluku sekaligus sebagai pulau induk dari hamparan pulau-pulau kecil di sekitarnya.

Sio tete manise jaga beta pung mamae. Penggalan lirik tersebut menunjukkan simbol keagungan (baca: Tuhan) yang dijadikan sandaran oleh orang-orang Maluku sebagai manifestasi penghambaan kepada Sang Pencipta, dengan menitipkan hal yang paling dicintai (baca: Ibu) kepadaNya. Bagi orang-orang Maluku, frasa manise tidak selalu hanya dimaknai manis (dalam pengertian mempunyai rona wajah yang khas dan menarik), akan tetapi dasar-dasar nilai keagungan juga sangat melekat di dalam pemaknaanya yang tersirat. Sebagai contoh misalnya, jika kita menyebut Ambon (ibukota Maluku), frasa ini selalu identik dan melekat sebagai satu kesatuan Ambon Manise yang menandakan betapa Ambon tidak hanya dimaknai sebagai satu kesatuan wilayah pada geografis tertentu yang penduduknya dikenal dengan perawakan yang hitam manis sebagai cermin kekuatan karakter orang-orang melayu, akan tetapi juga mempunyai keagungan di mata penduduk-penduduknya, serta senantiasa berada dalam lindungan Sang Maha Agung.

Toleransi, persaudaraan, kasih sayang dan perdamaian sesungguhnya adalah point penting yang selalu dijumpai dalam sajian petuah bijak masyarakat Maluku. Dalam tradisi pantong misalnya, penghargaan yang tinggi kepada pluralisme agama juga dijumpai dalam alunan dan artikulasi di setiap baitnya. Berikut contoh pantong yang memuat betapa toleransi antarumat beragama sudah berlangsung lama. (Lihat Mailoa, 2007: 1521).

Maluku pung banya suku memiliki banyak suku Banya lagu deng irama banyak lagu dan irama Juga penduduk di Maluku begitu juga penduduk di Maluku Punya macang-macang agama memiliki beragam agama

Dari Silo turong ka pante dari Silo turun ke pantai Basombayang Magrib di Jame bersembahyang Maghrib di Jame Basudara Salam, Sarane bersaudara Islam dan Kristen Hidop tenang deng rasa dame hidup tengang dengan rasa damai

Orang bilang di negeri ini orang bilang di negeri ini Ada lima macang agama ada 5 macam agama Dong hidop seng pikir sendiri kalian hidup jangan pikir sendiri Tapi mo hidup sama-sama tapi mau hidup bersama

Berita isu tamba banya berita isu tambah banyak Biking orang par jadi senu membuat orang menjadi takut Seng ada agama di dunya tidak ada agama di dunia ini Yang ajar orang baku bunu yang mengajarkan saling membunuh

\section{Dengar nasehat sang Ulama} dengarlah nasihat sang Ulama Kalu hidop musti bersama kalau hidup harus bersama Inga asas paleng utama ingatlah asas paling utama Amal bakti bagi sesama amal bakti bagi sesama manusia 
Akidah samua agama

akidah semua agama

Pasti seng ada yang berbeda

pastilah tidak ada yang berbeda

Musti saling hidop bersama

harus saling hidup bersama

Seng bole saling baku luda

tidak boleh saling meludah

Di Maluku, pantong menempati posisi penting dalam bermasyarakat. Pantong tidak hanya sekadar permainan kata-kata dan hiburan penyemarak suasana tetapi juga berfungsi sebagai media untuk memberikan "ujuk ajar" serta pewarisan nilainilai luhur budaya bangsa. Oleh karena pantong digunakan oleh semua lapisan masyarakat untuk mengungkapkan hasrat hati dan pikirannya, maka pantong merupakan teks sejarah yang menggambarkan realitas sosio-kultural Maluku secara turun temurun. Pantong merupakan media untuk berkomunikasi, melakukan pengajaran, dan membentuk jati diri.

Dalam kehidupan keseharian masyarakat Maluku, pantong selalu diperdengarkan, keberadaannya ibarat garam dalam makanan, betapapun makanan diolah dengan canggih tetapi jika tanpa garam, makanan tersebut tidak akan ketahuan enaknya. Lebih lanjut IR. Poedjawiyatna, menyatakan rasa kasih sayang, benci atau tidak suka itu tidaklah mudah, apalagi jika harus disampaikan secara langsung. Tetapi jika menggunakan pantong, mengucapkan, mengungkapkan rasa dan menyampaikan sindiran akan lebih mudah karena pantong dapat "mencubit tanpa menimbulkan rasa sakit". Mencermati hal ini, maka artikulasi nilai-nilai persaudaraan di dalam muatan pantong Maluku menjadi sebuah taman bahasa yang cantik. Dihiasi dengan ketinggian bahasa ibarat bunga berwarna-warni dengan wangi tanpa bandingan. Pemilihan katanya menarik, dan jika telah diucap bibir, maknanya akan segera singgah dalam ingatan terdalam, jikapun disampaikan dalam tulisan, korelasi antara kejenakaan yang berbanding lurus dengan kedalaman maknanya senantiasa terpatrih sepanjang hayat.

Sementara itu, dalam permainan jugulu-jugulu (teka-teki) penumbuhan akar persaudaraan juga dijumpai pada keseluruhan rangkaian permainan yang dimainkan. Suasana cair yang terjalin melalui dinamika jugulu-jugulu menunjukkan keakraban bagi para pemainnya. Suguhan unik dalam setiap pertanyaan yang dilontarkan bersinergi dengan pilihan jawaban yang diberikan seringkali menuai gelak tawa di antara mereka yang hadir. Jawaban yang diberikan tidak harus selalu benar, begitupula dengan pendekatan yang digunakan dalam menyusun pertanyaan-pertanyaan sangatlah unik, sehingga membawa intuisi yang berbeda antar pemain tergantung alasan yang dikemukakan, atas setiap pemilihan aksen dan logika berpikir menurut apa yang diutarakan berdasarkan pengalaman hidup mereka sehari-hari.

Semakin tinggi tingkat kesulitan dari pertanyaan yang diberikan, semakin menarik atmosfir jugulu-jugulu itu, dengan sendirinya akan ada banyak pilihan-pilihan jawaban yang keterhubungannya bisa dikaitkan dengan apa saja. Kebanyakan menunjukkan pola-pola khusus yang tidak terduga. Jugulu-jugulu hampir tidak mengikuti pola tertentu, ketidakteraturan itulah yang justru menjadi pintu masuk irama-irama kelucuan. Jika sudah begitu, peluang terjadinya lawakan-lawakan berikutnya semakin besar, sehingga karakteristik kejenakaan menjadi fenomena yang kehadirannya sangat dinantikan. Semakin lucu lontaran-lontaran tanya jawabnya, semakin membuat orang-orang yang terlibat disitu menjadi akrab, dengan demikian jarak sosial lama-kelamaan akan semakin sempit, bahkan bisa dikatakan tidak ada lagi. Semuanya larut dalam kegembiraan dan cinta tiada terkira. Nuansa persaudaraan sangat terasa, semua berkumpul dan bergembira satu dengan yang lain tanpa membedakan latar belakang sosial dan agama bagi mereka yang terlibat. Tidak jarang, simbol-simbol agama juga dijadikan sebagai bagian integral dalam isi jugulu-jugulu meski tidak secara keseluruhan dimaksudkan untuk menonjolkan agama tertentu. Kelazimannya menjadikan nuansa toleransi tetap terasa kental.

Kecil-kecil pakai songko', sudah besar buang songko' Apakah itu?

Jawaban: Bunga Cengkih

(cengkih yang masih kecil memiliki putik bunga yang diibaratkan seperti orang memakai songko' (kopiah) ketika cengkih menjadi besar maka putik cengkih (bunga) itu gugur (tidak lagi memakai songko')

Kupu-Kupu terbang sekawan

Dengan si ulat ia barana' 
Bila dipukul dengan tongkat

Susah dimuka terurai dua

Apakah itu?

\section{Jawaban: Nabi Musa di tepi laut Kolsum}

Ramai-Ramai duduk di jembatan

Angkat pantong seorang satu

Ramai-ramai duduk berhadapan

Angkat soal satu yang Tunggal

Jawaban: Murid-murid bertanya tentang Tuhan

Hidup yang ideal adalah kebersamaan, dalam bentuk saling menolong satu sama lain di dalam satu kerabat (marga), mematuhi orang tua dan tidak melupakan tanah air, karena itu tinggal di luar Maluku dan tidak memberi kabar sama sekali, digambarkan sebagai bagian dari individualitas, tidak mempunyai rasa kasih dan tidak dapat dipercaya. Hal ini tercermin sempurna pada lagu Rasa Sayange, lagu yang sempat diklaim oleh Malaysia sebagai lagu warisan budaya melayu ini sangat kental nuansa religi, persaudaraan dan kasih sayangnya. Berikut penggalan liriknya:

Rasa Sayang E Rasa Sayang-Sayang E Eee Lia Ambon Jau Rasa Sayang-Sayang E

Rasa Sayang E Rasa Sayang-Sayang E Eee Lia Maluku Suda Jau Rasa Sayang-Sayang EMana Kancil Akan Dikejar, Kedalam pasar cobalah cari

Masa Kacil Rajin Balajar, Suda Basar Sanang La Hati

\section{Si Amat Mengaji Tamat, Mengaji Quran diwaktu fajar}

Biar lambat asal selamat, Seng bole lari gunung dikejar

Kalu ada jarum yang pata,

Jang disimpan didalang peti

Kalu ada beta pung sala,

Jang ditumpuk didalang hati

Kalu ada sumur diladang boleh katong manumpang mandi

Kalu ada beta pung umur panjang Insya Allah bakudapa lai

Selipan-selipan keagamaan sepertinya menjadi sebuah aturan tidak tertulis yang nyaris selalu ada dalam setiap lirik-lirik lagu Maluku. Dia adalah konjungsi di tengah rambu-rambu ajaran, nilai, dan norma yang dimiliki agama dalam mendorong komunitas penganutnya untuk mencermati dan menilai lingkungannya serta melakukan perubahan sosial ke arah tertentu sesuai norma agamanya. Di sisi lain, kemungkinan doktrin yang ditanamkan itu bertabrakan dengan arah perubahan sosial yang diinginkan komunitas penganut agama lainnya tetap ada. Nah, di sinilah lalu isu-isu konflik, integrasi, akomodasi, asimilasi, dan kerjasama akan muncul yang selanjutnya terus akan bergulir sebagai rentetan proses perubahan sosial yang membutuhkan kearifan lokal dan penanaman nilainilai budaya sebagai alat perekat dan sinergitas masyarakat yang meskipun berbeda dalam hal prinsip aqidah dan kepercayaan, tetapi satu dalam toleransi dan persaudaraan dalam kerangka budaya lokal yang diperkuat.

\section{Dari ujung Halmahera sampai Tenggara jauh katong samua basudara satu nama satu gandong satu suku Maluku manise,}

Petikan lirik lagu Maluku Tanah Pusaka tersebut mencerminkan konstruksi kerukunan dari artikulasi religi sajak-sajak dan kasih sayang orangorang Maluku. Pemaknaannya yang sederhana namun tegas menunjukkan korelasi antara petuah bijak (pada berbagai ragam dan jenisnya) dengan keluhuran budi pekerti masyarakat Maluku dalam kreasi modernitas yang penghayatannya akan mengantarkan nuansa kerukunan dan kebersesamaan antar masyarakat menjadi semakin mengakar dalam jiwa raga manusianya.

\section{PENUTUP}

Penguatan pemahamanpetuat bijak berbasis keagamaan adalah sarana penanaman nilai luhur kebersesamaan yang pengamalan dan penghayatannya merupakan grand desain perwujudan sosio-kultural yang damai. Kekuatannya sangat besar sebagai sarana utama pencegahan konflik. Penggalian mendalam dari nilai yang diperoleh dari setiap kandungan kapata, nyanyian, pantong, jugulu-jugulu, dan pela gandong melalui setiap artikulasinya yang memuat pesan-pesan religi sangat potensial mewujudkan perdamaian, toleransi, persaudaraan dan kasih sayang. Kesemuanya menunjukkan relasi sosial yang tidak hanya sekadar menggambarkan prinsip hidup dan penghormatan 
antara satu dengan yang lainnya, tetapi pengamalannya dapat menumbuhkembangkan kerangka kasih sayang dan kerukunan hidup antar warga Maluku yang sangat heterogen, baik dari kesukuan maupun keagamaan. Pengamalan dan penghayatannya dapat mewujudkan sosok kontruksi manusia Maluku yang utuh dan integral sekaligus menjadi harmoni religi untuk meningkatkan diri dalam kesadaran kolektivitas sebagai hamba yang basodara.

\section{UCAPAN TERIMA KASIH}

Sebagai pranata akhir dalam tulisan ini, penulis menghaturkan banyak terima kasih kepada semua pihak yang telah membantu pelaksanaan penelitian ini, serta kepada redaksi Jurnal AlQalam Balai Penelitian dan Pengembangan Agama Makassar yang telah memuat tulisan ini. Jazakumullah Khairan Katsiran.

\section{DAFTAR PUSTAKA}

Abdul Kadir, Hatib. 2008. 'Romantisme Anak Muda dalam Lagu-Lagu Ambon'. Ilmu Komunikasi, $5 / 1$.

Cosmus Uneputty, Doms. tt. Hukum Adat Negeri Oma dan Perkembangannya.

J. Tamaela, Christian. 1995. 'Musik Tradisional Maluku sebagai Sarana komunikasi Injil dalam Jemaat GPM, Gereja Pulau-Pulau Toma Arus Sibak Ombak Tegar'. Ambon: Fakultas Theologi UKIM. dalam Maynart R.N. Alfons, Ansamble Musik Tifa Totobuang di Ambon.

Lestaluhu, Muhammad. 2012. Kerajaan Nunusaku (dalam Blognya Anak Ambon edisi Rabu,
18 Juli 2012. Diakses 30-10-2012 (http:// anakambonku.blogspot.com/2012_07_01_ archive.html).

Lewier, Mariana. 2012. Tradisi Pantong dalam Nyanyian Desa Letwurung Kepulauan Babar Maluku Tenggara Barat. Jurusan Pendidikan Bahasa dan Seni FKIP Universitas Pattimura Ambon, Makalah Publikasi Pdf Online, diakses 15 Oktober 2012.

Mailoa, Jan Piet. 2007. Kumpulang Pantong-pantong (bahasa harian dialek orang Ambon). Jakarta: Kitab 3, Kulibia Printing.

Ratnawati, Tri. 2006. Interactions Between Adat, Religious Institutions And The New Order State: Maluku dalam Catatan Seorang Peneliti. Cet I. Jakarta: Pustaka Pelajar.

Rosalina, Desy. 2012. Pela Gandong dalam Blognya: Manusia Daif, dipost July 2007. Diakses tanggal 14 Oktober 2012 (http://drosalina. blogspot.com/2007/07/pela-gandong.html)

Sahusilawane, Ny. F. dkk. 2002. Jugulu-Jugulu (TekaTeki Tradisional) Folklor Lisan Suku Ambon. Balai Kajian Sejarah dan Nilai Tradisional Propinsi Maluku.

Takaria, D. 2011. Buku Aneka Pantong Ambong, Cet. II. Maluku: Universitas Pattimura Ambon, Maluku.

Taman Budaya Maluku. 2004. Kapata: Nyanyian Tradisi di Maluku. Dinas Pendidikan dan Kebudayaan Provinsi Maluku.

Waileruny, Samuel. 2009. Anak Negeri di Maluku: Antara Konflik dan Damai. Tesis: Program Studi Sosiologi Pascasarjana Universitas Pattimura.

Watloly, Ahloiab. 2005. Maluku Baru (Bangkitnya Mesin Eksistensi Anak Negeri). Kanisius: Yogyakarta. 